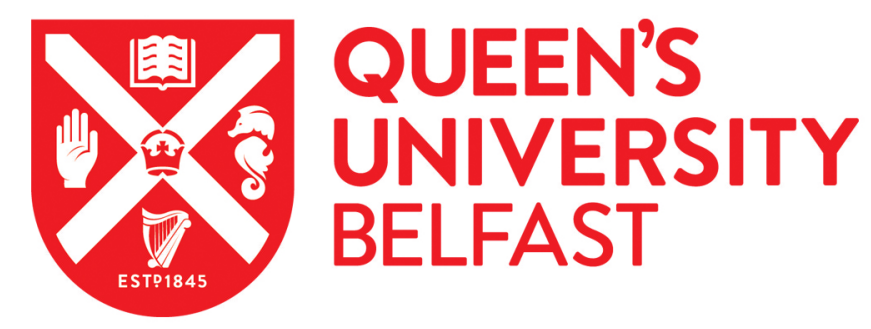

\title{
Northern Irish Legal Education After Brexit
}

Flear, M. L., \& Mac Sithigh, D. (2019). Northern Irish Legal Education After Brexit. The Law Teacher, 53(2), 148159. https://doi.org/10.1080/03069400.2019.1589745

\author{
Published in: \\ The Law Teacher
}

Document Version:

Peer reviewed version

Queen's University Belfast - Research Portal:

Link to publication record in Queen's University Belfast Research Portal

Publisher rights

(c) 2019 The Association of Law Teachers.

This work is made available online in accordance with the publisher's policies. Please refer to any applicable terms of use of the publisher.

\section{General rights}

Copyright for the publications made accessible via the Queen's University Belfast Research Portal is retained by the author(s) and / or other copyright owners and it is a condition of accessing these publications that users recognise and abide by the legal requirements associated with these rights.

Take down policy

The Research Portal is Queen's institutional repository that provides access to Queen's research output. Every effort has been made to ensure that content in the Research Portal does not infringe any person's rights, or applicable UK laws. If you discover content in the Research Portal that you believe breaches copyright or violates any law, please contact openaccess@qub.ac.uk. 


\title{
Northern Irish Legal Education after Brexit
}

\begin{abstract}
Mark L Flear and Daithí Mac Síthigh*
In this article we argue that the impact of Brexit on the law schools in Northern Ireland is tied to the 'unique circumstances' of legal education in this part of the world. Legal education in Northern Ireland is likely to develop to become even more distinctive than that in other parts of the UK. Although there are two distinct jurisdictions on the island, they are deeply entangled by shared history and geographical proximity that make cross-border practice a daily reality. These circumstances seem likely to drive the trajectory of the development of legal education in Northern Ireland. Indeed, EU law is likely to remain a component of the Northern Irish QLD. The potential for the development of law specific to Northern Ireland under backstop arrangements is another significant driver for the future orientation of legal education in this jurisdiction. Legal education in Northern Ireland is, therefore, likely to become noticeably more 'European' than that in other parts of the UK.
\end{abstract}

Keywords: Brexit, Northern Ireland, Legal Education, Qualifying Law Degree, Backstop

\section{Introduction}

In this article, we make an initial assessment of the potential impact of the United Kingdom's (UK's) withdrawal from the European Union (EU) (Brexit) on legal education in Northern Ireland. The academic stage of legal education in Northern Ireland takes place in two law schools: the School of Law, Queen's University Belfast (QUB Law) and the School of Law, Ulster University (UU Law). ${ }^{1}$ The training of barristers and solicitors in Northern Ireland takes place at the Institute for Professional Legal Studies (IPLS). Although we, the authors, are based at QUB Law, we seek to reflect on the implications of Brexit for Northern Irish legal education as a whole. We examine some of the key ways in which Brexit relates to wider changes in the provision of university legal education. We take note of further potential consequences for the provision of legal education in the Republic of Ireland (Ireland). These might have feedback effects on or help to concretise the potential changes wrought by Brexit on legal education north of the border. Throughout, we advance two tentative arguments: the impact of Brexit on the law schools in Northern Ireland is tied to the 'unique circumstances' of legal education in this part of the world, ${ }^{2}$ and the impact will differ from that expected in England and Wales due to the changes in professional qualifications for solicitors there.

Although it might be obvious, it is important to state the reason for our proviso. The impact of Brexit on the law school in Northern Ireland, as elsewhere in the UK, is contingent on the meaning of Brexit - which during the drafting and review of this article, and up to its publication, has remained unclear. We can, however, observe there are likely to be consequences that emerge from Brexit for legal education in Northern Ireland, whatever form 'Brexit' eventually takes. These consequences are

\footnotetext{
${ }^{*}$ Our thanks to Tammy Hervey for the invitation to contribute. We are very grateful to Frank Geddis, Head of Research and Governance, Law Society of Northern Ireland, for providing much insight on that organisation's position on Brexit, and to Rory O'Connell, School of Law, Ulster University, for providing statistics. Many thanks to the reviewer for invaluable comments that have enriched the article and its contribution.

${ }^{1}$ Referred to in this order simply because it is alphabetical.

${ }^{2} \mathrm{~A}$ term that has been used to describe the position of Northern Ireland in respect of Brexit in the recitals to the Protocol on Ireland / Northern Ireland of the Agreement on the Withdrawal of the United Kingdom of Great Britain and Northern Ireland from the European Union and the European Atomic Energy Community, as endorsed by leaders at a special meeting of the European Council on 25 November 2018 - 'Recognising that it is necessary to address the unique circumstances on the island of Ireland through a unique solution in order to ensure the orderly withdrawal of the United Kingdom from the Union' (emphasis added). For discussion of this term and related issues, see: Dagmar Schiek, 'Brexit on the Island of Ireland: Beyond Unique Circumstances' (2018) 68(3) Northern Ireland Legal Quarterly 367.
} 
related to the specifics of professional legal education in Northern Ireland, i.e. 'unique circumstances', and the relationship with requirements for the legal profession elsewhere in the UK. Moreover, the upcoming changes to the qualification route for those law students seeking to become a solicitor in England and Wales may also have an impact on the Northern Irish law schools.

We begin, in the next section (2) with some essential background through a sketch of the "unique circumstances' of legal education in Northern Ireland, including specific features of professional legal education here as compared with England and Wales. Subsequently, we highlight, in Section 3, those changes that are a direct consequence of Brexit or at least related to it to a discernible extent. We suggest that EU law is likely to remain a component of the Northern Ireland Qualifying Law Degree (QLD) despite Brexit, because of the recognition of qualifications (especially in Ireland) and because of the role of EU law itself in post-Brexit Northern Ireland. In Section 4, we discuss the possible change in the composition of Northern Ireland law schools and career pathways post-Brexit, before concluding in Section 5.

\section{Setting the Scene: 'Unique Circumstances' of Legal Education in Northern Ireland}

In 2016/2017 QUB Law had a total of 1,300 students registered for undergraduate and postgraduate programmes, whereas UU Law has a total of $820 .{ }^{3}$ For 2018/19 QUB Law has, according to the data currently available to us, 934 full-time students and 4 part-time students registered on its undergraduate programmes. QUB Law also has 221 full-time and 35 part-time students registered on its postgraduate programmes. As for UU Law, according to the data provided to us, there are 421 fulltime students and 117 part-time students registered on its undergraduate programme. UU Law also has 49 full-time and 23 part-time students registered on its postgraduate programmes. To delve into the data on student recruitment on QLD programmes at QUB Law, which is by far the larger provider of university legal education in Northern Ireland, sheds further light on the overall picture of who it is studies law in Northern Ireland law schools. In short, the majority of students (just under two thirds) studying QLD programmes at QUB Law are from (that is, resident in) Northern Ireland. Most of the rest (around a third) are international students (including EU students, although EU students would of course (currently i.e. pre-Brexit) study on the same basis as UK nationals). Just one twentieth (or 5 per cent) of the total number of student come from elsewhere in the UK i.e. Great Britain.

Both QUB Law and UU Law offer QLDs. The QLD is not referred to as such in the regulations applicable to either solicitors or barristers. This status is conferred by the applicable regulations of the Law Society of Northern Ireland (LSNI) ${ }^{4}$ and the Inn of Court of Northern Ireland respectively. ${ }^{5} \mathrm{We}$ use the term here as a general term. Holding a QLD is one of the prerequisites for admission to the profession of solicitor and barrister via the law degree route.

For solicitors the other main elements of professional training relate to formal vocational instruction provided by the IPLS, leading to a postgraduate Diploma in Professional Legal Studies, and practical in-office training provided by a master. The latter is a solicitor with whom the applicant served his/her apprenticeship. For barristers the other main elements of professional training relate to formal vocational instruction provided by the IPLS, leading to a Diploma in Professional Legal Studies, and being called to the Bar of Northern Ireland and completing a 12 month pupillage provided by a master. Although the possession of a degree in law is one route into both professions, such degrees must include eight subjects in order to constitute QLDs - one of which is EU law, which is referred to

\footnotetext{
${ }^{3}$ Figures obtained from the Higher Education Statistics Agency, see: https://www.hesa.ac.uk/data-andanalysis/students/where-study [last accessed 11 January 2019].

${ }^{4}$ Article 8(1) Solicitors Admission and Training Regulations 1988 as amended.

${ }^{5}$ Rule 9(4) Rules of the Honorable Society of the Inn of Court of Northern Ireland.
} 
as 'European law'. ${ }^{6}$ It should be noted that this list also differs from that currently operated in England and Wales, in that the law of evidence is a requirement in Northern Ireland.

The QLD process in Northern Ireland otherwise mirrors that in England and Wales. To underscore this point, we briefly take note of the process in England and Wales. ${ }^{7}$ There, the applicable regulations also provide that a QLD is one of the prerequisites for admission to the profession of solicitor and barrister via the law degree route. For solicitors the other main elements of professional training, at present, relate to formal vocational instruction obtained through a Legal Practice Course, leading to a period of practical in-office training. For barristers the other main elements of professional training relate to formal vocational instruction obtained through a Bar Professional Training Course, and being called to the Bar of England and Wales and undertaking a pupillage or in-work training. In respect of solicitors in England and Wales, it is envisaged that the Solicitors Qualifying Examination will be introduced from September 2020 to replace the current systems to become a solicitor there. The changes in respect of solicitors have no application to the Bar in England and Wales. The assessments required to qualify as a barrister in England and Wales will not change.

\section{EU Law in Northern Ireland and Ireland}

As we have just noted, 'European law' is an integral component of the QLD in Northern Ireland. Moreover, as the legal profession in Northern Ireland operates autonomously, planned changes in England and Wales would not, without more, affect the QLD in Northern Ireland. It must therefore be assumed that the concept of the QLD and of prescribed subjects, including EU law - for aspirant barristers and solicitors - will continue to be a part of Northern Irish arrangements. Public statements issued by the Law Society of Northern Ireland (LSNI), at least, have been vehement in their call for maintenance of current professional practice and the development of future legal arrangements between the EU and UK post-Brexit that help to make this possible. This implies that EU law will remain central to university legal education as the foundation for practice. As the LSNI states, postBrexit:

'Transitional arrangements should be put in place to manage the complexities of withdrawal from the EU, which recognise that whilst the UK is withdrawing from the institutional and political structures of the EU, mutually beneficial agreements should not be a casualty of this process as this would damage all parties'.

Further, the importance of reciprocity and mutual recognition to the practical and commercial reality of legal practice, and the protection of clients' rights before the courts, provides the overriding rationale for the LSNI's position, and thus the continued centrality of EU law to Northern Irish legal education. As the LSNI explains:

'Recognition of legal qualifications and rights of establishment for legal professionals underpin cross-border commercial relationships and allow UK and EU lawyers to represent their clients in each other's respective courts. These agreements, carefully crafted over a number of years, should remain in place to ensure neither sector is competitively impaired. The Society anticipates this will be possible, however we urge that in the worst case scenario that changes are made to these arrangements, the mutual recognition of lawyers between Northern Ireland, Republic of Ireland and the rest of the UK should continue'. ${ }^{9}$

\footnotetext{
${ }^{6}$ EU or European law took the place of Company Law in September 1996.

${ }^{7}$ See further: https://www.lawsociety.org.uk/law-careers/becoming-a-solicitor/qualifying-as-a-solicitor/ and https://www.barstandardsboard.org.uk/qualifying-as-a-barrister/ [last accessed 27 February 2019].

${ }^{8}$ Law Society of Northern Ireland, The United Kingdom's Withdrawal from the European Union: Position Paper, November 2017, 1. Emphasis added.

${ }^{9}$ Ibid, 2. Emphasis added.
} 
In fact, under the Agreement on the Withdrawal of the United Kingdom of Great Britain and Northern Ireland from the European Union and the European Atomic Energy Community, as endorsed by leaders at a special meeting of the European Council on 25 November 2018 (the Withdrawal Agreement or WA), it is provided that, if it is agreed, during the transition period ${ }^{10} \mathrm{EU}$ law would continue to apply in the UK and its citizens would enjoy the same rights, including to mutual recognition and free movement, ${ }^{11}$ as they currently do. It is not possible to state what will be the situation post-transition, including in respect of legal services, since these are not covered in the WA, and arrangements for after the end of the transition period have not yet been agreed between the EU and the UK. Relatedly, under the European Union (Withdrawal) Act 2018, which provides that the UK will leave the EU on "'exit day" which 'means 29 March 2019 at 11.00 pm', ${ }^{12}$ the category of 'retained EU law' is created. ${ }^{13}$ This new category of UK law has an important implication for university legal education. This is because EU law will continue to be relevant to the interpretation of retained EU law. ${ }^{14}$ As such the new category of UK law will require law students and legal practitioners across the UK to continue to have some knowledge of EU law. Overall, these statements from the LSNI and the formal legal position suggest that, at least from the position of Northern Ireland's professional organisations, EU law will remain integral to their expectations and requirements for university legal education. This holds irrespective of the uncertainty over any transition period after exit day and post-transition, and indeed over whether Brexit will happen at all and if so in what way.

Indeed, we propose that both the existing strong links between legal practice on both sides of the border, and the significance of EU law within the Northern Irish legal system, point to a likelihood that EU law will continue to be a requirement for the Northern Irish QLD post-transition. Of course, Northern Irish law schools will make their own decisions on whether to continue offering EU law, whatever decisions are made regarding professional requirements in Northern Ireland or indeed elsewhere in the UK. However, we think it is unlikely Northern Irish law schools will stop offering EU law and QLDs. We provide further specificity for our proposal by grouping the reasons why EU law is likely to remain important into two bundles of issues that relate to the 'unique circumstances' of legal education in Northern Ireland. The first group of reasons is lengthier and pertains to the recognition of qualifications. The second group relates to the law of Northern Ireland.

\section{Reciprocity and Recognition}

In terms of the cross-border dimension, our first reason to expect EU law will remain a component of the Northern Ireland QLD for the foreseeable future, is there is an existing set of reciprocal arrangements for the recognition of professional qualifications between the two jurisdictions (and indeed between other UK jurisdictions and Ireland). ${ }^{15}$ Reciprocal recognition preceded the accession

\footnotetext{
${ }^{10}$ After the date envisaged for Brexit i.e. 29 March 2019, there will be a 21-month transition period which, under Article 126 Agreement on the Withdrawal of the United Kingdom of Great Britain and Northern Ireland, if agreed, would end on 31 December 2020.

${ }^{11}$ Note, in particular, Article 5 on the Common Travel Area between the Republic of Ireland and the United Kingdom.

${ }^{12}$ Section 20(1) European Union (Withdrawal) Act 2018.

${ }^{13}$ Section 7(1) European Union (Withdrawal) Act 2018 provides: 'Anything which - (a) was, immediately before exit day, primary legislation of a particular kind, subordinate legislation of a particular kind or another enactment of a particular kind, and (b) continues to be domestic law on and after exit day by virtue of section 2 , continues to be domestic law as an enactment of the same kind'.

${ }^{14}$ On interpretation of retained EU law, see Section 6 European Union (Withdrawal) Act 2018.

15 The earliest reference we can find is Section 44 Solicitors Act 1954, which was the first comprehensive revising legislation on the profession in post-independence Ireland. This allowed, in short, for solicitors admitted to practice in Northern Ireland, with three years standing, to gain similar rights in the Republic of Ireland through presenting their certificate, but not the full set of exams, apprenticeship, etc. This provision would however only come into force once there was a reciprocal provision in Northern Ireland, which there never was, so it never came into force.
} 
of the UK and Ireland to the European Economic Community (now the EU) in 1973. The current position is that a solicitor of three years standing in England or Northern Ireland can go straight into practice in the Republic of Ireland. ${ }^{16}$ This is not part of the scheme based on rights under EU law. ${ }^{17}$

Although the professional qualifications in law (as distinct from some other professions) do not follow automatically from the study of law at a university, there are clear links between the university and professional dimensions. These matters are nowadays underpinned by the mutual recognition of qualifications provided by EU law, ${ }^{18}$ as expressly recognised throughout the regulations of the legal professions on the island of Ireland and noted before the Council of Bars and Law Societies of Europe (known as the CCBE). ${ }^{19}$ Furthermore, the relationship between Northern Ireland and Ireland must be, as is well known in light of recent debates, understood in light of the Good Friday / Belfast Agreement. For instance (as we discuss in more detail in Section 5, below), many graduates of Northern Ireland law schools and of the professional training programmes will be dual UK and Irish citizens.

In order to fully understand this point, we must also assess the legal education landscape in Ireland. Access to the legal profession in Ireland also requires the study of EU law. It is taught as a compulsory module at all of the Irish law schools. As regards barristers, the Honourable Society of King's Inns is responsible for professional training for the Irish Bar and recognises law degrees in a 'Schedule of Approved Degrees'. ${ }^{20}$ The Honourable Society admits students to its qualification programme provided they have passed six required subjects during such an approved degree; EU law is one of these six subjects. Most of the programmes on this Schedule of Approved Degrees are offered by higher education institutions in Ireland. Both the single honours and joint honours LLB programmes offered by QUB Law are included in the Schedule, as is the LLB at UU Law. ${ }^{21}$ Programmes in England and Wales and in Scotland are however not included. ${ }^{22}$

\footnotetext{
${ }^{16}$ See: 'Qualified Lawyers Transfer Test Regulations' https://www.lawsociety.ie/globalassets/documents/education/qltt/certadminform.pdf [last accessed 11 January 2019]. The legal basis for this exemption appears to be Section 4(4) Statutory Instrument 85/1991. These expressly exempted from the requirements applicable to (then) European Economic Community nationals from mutual recognition and requirements that flow from the principle, such as the provision of an aptitude test - see fn 18 below.

17 'EU Registered Lawyers' https://www.lawsociety.ie/Public/Foreign-Lawyers/EU-Registered-Lawyers/ [last accessed 11 January 2019].

${ }^{18}$ A cluster of legislation applies: Council Directive of 22 March 1977 to facilitate the effective exercise by lawyers of freedom to provide services OJ L 78/ 17; Directive 98/5/EC of the European Parliament and of the Council of 16 February 1998 to facilitate practice of the profession of lawyer on a permanent basis in a Member State other than that in which the qualification was obtained OJ L 77/36; Directive 2005/36/EC of the European Parliament and of the Council of 7 September 2005 on the recognition of professional qualifications OJ L 255/22. In addition, the underlying justification for the mutual recognition of qualifications, and requirements that flow from it including aptitude tests, derives from Case C-340/89 Vlassopoulou v Ministerium für Justiz [1991] ECR I-02357 (ECLI:EU:C:1991:193).

${ }^{19}$ UK Delegation Paper, EU Lawyers in the UK - Practice Rights under the Draft Withdrawal Agreement and $Q \& A, 1$.

${ }^{20}$ The Schedule is updated annually; the current version appears at: 'Schedule of Approved Degrees' https://www.kingsinns.ie/cmsfiles/entrance-examination/ScheduleOfApprovedDegrees2018.pdf [last accessed 12 October 2018].

${ }^{21}$ There is an alternative route available: a Northern Ireland-qualified barrister can apply for admission to the Irish bar, subject to three years of practice in Northern Ireland and other requirements, but without further examination.

${ }^{22}$ A small number of programmes formally awarded (validated) by English or Welsh institutions, but delivered in practice to students at locations in Ireland, are also included. This arises where a private-sector provider in Ireland (which does not possess degree-awarding powers of its own) enters into an arrangement with a UKbased university.
} 
The position is different regarding solicitors. The initial examination conducted by the Law Society of Ireland (for those who seek to qualify, in due course, as solicitors) is open to graduates of any UK or Irish degree, ${ }^{23}$ but includes eight papers in law - one of which is EU law. ${ }^{24} \mathrm{~A}$ law graduate who has studied EU law is therefore in a good position to attempt this examination without extensive further study, even if the module is not a formal requirement.

Reflecting on the implications of the history and reality of legal practice on the island of Ireland, the LSNI observes:

'The shared common law traditions and history across these islands make the professions highly integrated and qualification in one jurisdiction should mean recognition in another. Any dilution of this integration is unacceptable and does not recognise the practical realities of professional relationships in these islands. We welcome the recognition by both parties [i.e. the EU27 and the UK] that this is a unique relationship and would strongly caution against any unpicking of historical ties which predate the European Union itself. Custom and practice for this is well established and it reflects the importance of lawyers representing cross-border clients seamlessly, ${ }^{25}$

Moreover, the principle of mutual recognition has been noted as being of wider importance to the future shape of relations between the EU and UK post-Brexit. For example:

'The parties [i.e. the EU27 and UK] will be aware of the provisions of the Foreign Judgments (Reciprocal Enforcement) Act 1933, which put in place bilateral reciprocity in terms of enforcement of judgments between the UK and other countries. This included the current EU countries of Germany, France, Italy and Belgium. Reversion to an arrangement of piecemeal recognition and a high level of uncertainty as to the application of these agreements would be a retrograde step. This legislation demonstrates that the principle of mutual recognition predates the EU and confirms the close ties between the UK and the EU should point towards continuing mutual recognition as a priority'. ${ }^{26}$

This statement further underlines the way in which the LSNI sees mutual recognition as a key underpinning for future relations between the EU and the UK, including Northern Ireland. This and the previous statement lend further normative weight to mutual recognition as a principle that will undergird legal practice on the island of Ireland. Indeed, we can expect that mutual recognition, as part of custom and practice, and pre-EU arrangements across these islands and between the UK and other European countries, will continue to shape future arrangements between the legal professions of (at least) Northern Ireland and Ireland post-Brexit.

The upshot is that the importance of EU law to access to the Irish legal profession, combined with custom and practice and the reality of and need for seamless practice across the border (discussed further, below), operates as a key driver for the maintenance of EU law as a part of legal education provided in Northern Ireland law schools. Hence, although EU law might be taught as part of international trade law in England and Wales, ${ }^{27}$ this change does not compel a similar change in Northern Ireland. Although quite tangential and remote from the present discussion, it is also worthwhile noting that Brexit has moved discussions about a border poll (i.e. unification of the two

\footnotetext{
${ }^{23}$ Non-graduates take a 'preliminary examination' covering language, politics, and the like, before taking the legal examination.

24 'FE-1 Exam' https://www.lawsociety.ie/Public/Become-a-Solicitor/FE-1-Exam/ [last accessed 12 October 2018]. It is worthwhile to those that private preparatory courses are available, so an applicant without knowledge of EU law could attempt the examination after such a course.

${ }^{25}$ Law Society of Northern Ireland, note 8 above, 2. Emphasis added.

${ }^{26}$ Ibid. Emphasis added.

${ }^{27}$ See papers by Jeffrey Kenner and Phil Sypris, 'What Will Happen to the EU Law Module?', at the workshop preceding this special issue.
} 
parts of the island of Ireland) in from the margins of political discourse in Northern Ireland. This does not seem to operate as a key reason to continue to emphasise EU law in Northern Ireland legal education. However, the latter could quickly change, depending on the conceivable political futures that come into view as a consequence of the Brexit process (whether or not it leads to Brexit).

\section{Northern Irish Law}

A second good reason to expect that EU law will remain a component of the Northern Ireland QLD, in the near term and into the future, relates to the fact of a jurisdiction of Northern Ireland. Northern Ireland is one of the three jurisdictions in the $\mathrm{UK} ;{ }^{28}$ this has been the case since the Government of Ireland Act 1920. From then until 1972, and again (on and off) since 1998, it has - separately - been subject not just to Westminster legislation but to the legislation made by the pre-1972 Parliament of Northern Ireland and the post-1998 Northern Ireland Assembly respectively. Some Westminster legislation also makes special provision for Northern Ireland, including but not limited to the various legal responses to the 'Troubles'.

So, although there are many similarities between the law of England and Wales ${ }^{29}$ on one hand and the law of Northern Ireland on the other (which allows for a great deal of overlap in terms of teaching, and much closer alignment than in the distinctive case of the Scottish legal system), there are also differences. Under the regulatory alignment required under the so-called 'backstop' arrangements that are provided for under the Protocol on Ireland / Northern Ireland to the WA, ${ }^{30}$ Northern Ireland would enjoy a special status in order to avoid a 'hard border' with Ireland. Provided the WA itself is agreed, the provisions of the Protocol would apply from the date of entry into force of the WA, and 'unless and until they are superseded, in whole or in part, by a subsequent agreement ${ }^{31}$

There is nothing specific in the backstop arrangements relating to the recognition of legal (or indeed other) qualifications, the freedom of establishment (including branches) of law firms, or the provision (or receipt) of legal (or indeed other) services. Instead, the Protocol, like much of the WA itself, is focused on ensuring the free movement of goods. ${ }^{32}$ Indeed, under the backstop arrangements, the whole of the UK would enter into a customs union with the EU. This would mean that customs checks on goods travelling between Northern Ireland and Ireland would not be necessary. Moreover, EU law on goods would continue to apply to Northern Ireland. These arrangements are designed to ensure the maintenance of an open border between Northern Ireland and Ireland. In short, the arrangements mean there would be no need for checks on products crossing the border in order to ensure their compliance with EU standards. There would, however, need to be new checks put in place on goods travelling between Northern Ireland and the rest of the UK. ${ }^{33}$ In light of these arrangements, it may

\footnotetext{
${ }^{28}$ Brice Dickson, Law in Northern Ireland (3 ${ }^{\text {rd }}$ edn, Hart Publishing 2018).

${ }^{29}$ Setting aside the separate debate about whether Wales could be a fourth jurisdiction in the UK, see: Richard Percival, 'How to Do Things with Jurisdictions: Wales and the Jurisdiction Question' [2017] PL 249.

${ }^{30}$ Referred to as 'the backstop solution on Northern Ireland' in the recitals to the Protocol on Ireland / Northern Ireland of the Agreement on the Withdrawal of the United Kingdom of Great Britain and Northern Ireland.

${ }^{31}$ Article 1(4) Protocol on Ireland / Northern Ireland of the Agreement on the Withdrawal of the United Kingdom of Great Britain and Northern Ireland. Article 2(1) of the Protocol provides the 'Union and the United Kingdom shall use their best endeavours to conclude, by 31 December 2020, an agreement which supersedes this Protocol in whole or in part'. 31 December 2020 is also the date for the end of the transition period, at which point there will either be a deal between the UK and the EU on their future relationship(s) or no deal. To complicate matters, Article 132(1) Agreement on the Withdrawal of the United Kingdom of Great Britain and Northern Ireland provides 'Notwithstanding Article 126, the Joint Committee may, before 1 July 2020, adopt a single decision extending the transition period for up to one or two years'.

${ }^{32}$ Article 6 Protocol on Ireland / Northern Ireland of the Agreement on the Withdrawal of the United Kingdom of Great Britain and Northern Ireland.

${ }^{33}$ It is conceived that these checks would take place in factories and farms, instead of the border between Northern Ireland and Ireland. Such checks would not be possible in respect of live animals, meaning that border checks would be necessary.
} 
also be the case that legislative provisions and associated jurisprudence will develop along distinctive lines in Northern Ireland. If aspects of Northern Irish law see more of an EU dimension, particularly as a result of these backstop arrangements, then these areas will be important in legal education (and perhaps see continued engagement with EU law above and beyond what will be the case in other UK jurisdictions).

\section{Composition and Careers}

Although we observe that it is highly likely that EU law will remain central to legal education in Northern Irish law schools, this does not necessarily mean that there will be no change in legal education due to Brexit. In particular, we think it important to consider the impact of Brexit on the composition of staff and students. In this respect, the 'unique circumstances' of legal education in Northern Ireland are relevant once more.

There is already an increase in non-EU students within Northern Ireland law schools as a percentage of the overall student body - as noted above in Section 2, around a third of QUB Law QLD students are nowadays international students (that is, students from outside the UK or EU). This is consistent with broader changes in higher education in the UK and beyond - pursuing goals of internationalisation and of diversifying sources of income. We wonder, however, whether Brexit might generate an increase in students from Great Britain, especially England and Wales, in the event that EU law is no longer a requirement in the academic stage of training there. Put differently, would students from Great Britain be tempted to undertake a QLD in a Northern Ireland law school in order to obtain legal knowledge in EU law? Would a Northern Irish law degree be pitched differently to potential international students, emphasising the coverage of both UK and EU law?

If this were to happen, it could also provide such students with a basis on which to access the Irish legal profession. Even in the absence of mutual recognition of qualifications under EU law or as part of post-Brexit arrangement(s), Irish authorities will continue to have the power to decide whether to recognise Northern Ireland professional qualifications and titles as meeting domestic professional requirements. ${ }^{34}$ Such recognition would, in turn, support the exercise of related freedom of services and establishment rights around the $\mathrm{EU}^{35}$ - provided, of course, that other criteria are met (i.e. Irish citizenship, rights as a consequence of being a citizen of another EU Member State, or post-Brexit rights as a UK citizen).

Moreover, if Irish citizens resident in Northern Ireland have strong access to EU rights (on the simple basis of being Irish citizens with free movement rights when in the EU), or even more so if being an Irish citizen in Northern Ireland is different to being an Irish citizen in Great Britain (see below), this could affect the attractiveness of work and study in Northern Ireland. A high proportion of Northern

\footnotetext{
${ }^{34}$ That is, as 'competent authorities' under Article 3(1)(d) Directive 2005/36/EC: 'any authority or body empowered by a Member State specifically to issue or receive training diplomas and other documents or information and to receive the applications, and take the decisions, referred to in this Directive'.

${ }^{35}$ Article 2(2) Directive 2005/36/EC provides 'Each Member State [i.e. in this case Ireland] may permit Member State nationals in possession of evidence of professional qualifications not obtained in a Member State to pursue a regulated profession within the meaning of Article 3(1)(a) on its territory in accordance with its rules. In the case of professions covered by Title III, Chapter III, this initial recognition shall respect the minimum training conditions laid down in that Chapter' (emphasis added). Moreover, pursuant to Article 13(1) Directive 2005/36/EC, where the competent authorities in such a Member State (i.e. in this case Ireland) provides its nationals with a training qualification which attests to a level of training at least equivalent to the level immediately below that required in another Member State (post-Brexit, one of the EU27 countries), the competent authority in another Member State may not refuse to authorise the national of that other Member State access to, and indeed pursuit of, the profession under the same conditions that apply to its own nationals. This would seem to encompass situations where the training qualification provided (i.e. in Ireland) recognises professional qualifications not obtained in a Member State (i.e. in this case, not in Ireland, but in Northern Ireland, or for that matter another part of the UK).
} 
Ireland law graduates will (as compared with graduates from England and Wales and from Scotland) hold Irish passports or be entitled to acquire one as of right. In 2017, just over half of the 163,000 Irish passports issued to applicants resident in the UK were issued to Northern Ireland residents. ${ }^{36}$ Anyone born in Northern Ireland is either an Irish citizen as of right (if born before 2005) or subject to the (Northern Ireland or RoI) citizenship/residency of parents (for births from 2005 onwards), whereas those born in England and Wales are generally treated in the same way as those born anywhere in the world. These statutory provisions reflect the Constitution of Ireland ${ }^{37}$ (as amended in 2004 to remove jus soli) and the Good Friday / Belfast Agreement. ${ }^{38}$ There is no requirement that a Northern Ireland-resident citizen of Ireland reside in Ireland, forego British citizenship, pass any test, or make any declaration of loyalty. Unsurprisingly, the trend is towards more Irish passport applications by Northern Ireland residents, which have doubled over the last five years. ${ }^{39}$

Assuming that free movement remains possible across the border between Northern Ireland and Ireland, Northern Ireland law graduates could maintain a cross-border practice with residence on either (or both) side(s) of the border. They could move to practice exclusively in Ireland. Where such graduates are Irish citizens, they may have further opportunities within the EU. In some circumstances, this may flow from membership of the group defined as the "people of Northern Ireland ${ }^{40}$ (which includes Irish citizens born in Northern Ireland) or on the wider basis of Irish citizenship alone; this latter category would include, for instance, Irish citizens born in Great Britain or the Republic of Ireland. It has been contemplated that 'the people of Northern Ireland who are Irish citizens' be able to exercise EU citizen rights; ${ }^{41}$ if such or similar is confirmed, further opportunities for continued engagement with the EU should arise.

One concrete example of the relevance of EU citizenship is eligibility for legal and other posts in the EU institutions, in situations where EU citizenship is a requirement. ${ }^{42}$ Of narrower appeal, though still demonstrating the distinctive circumstances of Northern Ireland, would be the ability of a Northern

\footnotetext{
${ }^{36}$ Northern Ireland: 82274; Great Britain: 80752. See https://www.dfa.ie/passporttracking/passportstatistics/ [last accessed 12 October 2018].

${ }^{37}$ Article 2 Constitution of Ireland: 'It is the entitlement and birthright of every person born in the island of Ireland, which includes its islands and seas, to be part of the Irish Nation. That is also the entitlement of all persons otherwise qualified in accordance with law to be citizens of Ireland'; Article 9(2): '1. Notwithstanding any other provision of this Constitution, a person born in the island of Ireland, which includes its islands and seas, who does not have, at the time of the birth of that person, at least one parent who is an Irish citizen or entitled to be an Irish citizen is not entitled to Irish citizenship or nationality, unless provided for by law; 2 . This section shall not apply to persons born before the date of the enactment of this section'.

${ }^{38}$ Article 1(vi) Belfast Agreement: 'The participants in the multi-party negotiations ... recognise the birthright of all the people of Northern Ireland to identify themselves and be accepted as Irish or British, or both, as they may so choose, and accordingly confirm that their right to hold both British and Irish citizenship is accepted by both Governments and would not be affected by any future change in the status of Northern Ireland'; see also the associated British-Irish Agreement, Article 1(vi), expressing the same commitment of both Governments. 39 2012: 41,124; 2017: 82,274. See 'Passport Statistics' https://www.dfa.ie/passporttracking/passportstatistics/ [last accessed 29 January 2018].

${ }^{40}$ The British-Irish Agreement (Annex 2) refers to the 'people of Northern Ireland', for the purposes of Article 1(vi), as 'all persons born in Northern Ireland and having, at the time of their birth, at least one parent who is a British citizen, an Irish citizen or is otherwise entitled to reside in Northern Ireland without any restriction on their period of residence'. On the significance of this clause in the context of Brexit, see e.g. J Doyle and E Connolly, 'Brexit and the Northern Ireland Question' in F Fabbrini, The Law and Politics of Brexit (OUP 2017) 157; C Murray and others, 'Discussion Paper on Brexit' (Irish Human Rights and Equality Commission 2018) 29-31, available at: https://www.ihrec.ie/app/uploads/2018/03/Discussion-Paper-on-Brexit.pdf [last accessed 12 October 2018].

${ }^{41}$ Framework Agreement December 2017, para 52: 'The people of Northern Ireland who are Irish citizens will continue to enjoy rights as EU citizens, including where they reside in Northern Ireland'. The extent to which this will be possible in practice remains under discussion, as do the parameters of this category. See: Sylvia de Mars and others, Bordering Two Unions: Northern Ireland and Brexit (Polity 2018), 66.

42 e.g. Staff Regulation.
} 
Ireland resident with Irish citizenship, who has sufficient knowledge of the Irish language ${ }^{43}$ (which has official status in the EU), to rely upon such combination of citizenship and language ability to satisfy certain requirements for those seeking EU jobs. ${ }^{44}$

There are further possible implications for staff recruitment of the ongoing centrality of EU law to the law curriculum in Northern Irish law schools post-Brexit. Northern Irish law schools will, if our analysis bears out, still require staff who teach and research EU law. This would, in turn, imply that the mix of staff in Northern Irish law schools, both in terms of nationality and teaching and research interests, will, post-Brexit, become more EU-oriented than within other UK law schools.

Finally, it can be noted that around 2,000 students from the Republic of Ireland currently study in Northern Ireland. ${ }^{45}$ The Irish government has confirmed that such students will, for those starting in 2019/20 at least, continue to be eligible to receive financial support (i.e. maintenance grants) under the Student Universal Support Ireland scheme; ${ }^{46}$ these students are not eligible for support from Student Finance NI as they are not ordinarily resident in Northern Ireland. In terms of fees, these students currently pay 'EU' fees (which are the same as the fees paid by Northern Ireland residents, and around half of what 'GB' students pay to study in Northern Ireland), and can receive a loan from Student Finance NI in respect of this amount. Changes to any of these schemes may affect the willingness of students to cross the border for higher education.

\section{Conclusion}

In this article we have argued that the impact of Brexit on the law schools in Northern Ireland is tied to the 'unique circumstances' of legal education in this part of the world. In particular, the impact of Brexit (if it transpires) can be expected to differ from that expected in England and Wales due to the changes in professional qualifications for solicitors there. In short, the circumstances in Northern Ireland are unique in light of the intertwinement of the legal profession on the island of Ireland. Although there are two distinct jurisdictions on the island, they are deeply entangled by shared history and geographical proximity that make cross-border practice a daily reality.

These circumstances seem likely to drive the trajectory of the development of legal education in Northern Ireland. As such EU law is likely to remain a component of the Northern Irish QLD. In this respect, given moves away from the QLD in England and Wales, and assuming that Brexit would drive the teaching of EU law as international trade law elsewhere in the UK, legal education in Northern Ireland is likely to develop to become even more distinctive than that in other parts of the UK. The potential for the development of law specific to Northern Ireland under backstop arrangements is another significant driver for the future orientation of legal education in this jurisdiction. Legal education in Northern Ireland is, therefore, likely to become noticeably more 'European' than that in other parts of the UK. Yet, Brexit is only part of the reason for this: changes in the law degree pathway to professional qualification for solicitors in England and Wales, something that is not related to Brexit, is another key driver. The comparative 'European-ness' of legal education in Northern Ireland might also be apparent in respect of increases in the number of students studying for their QLD, and with it EU law, and in education practitioners and researchers.

\footnotetext{
${ }^{43}$ Around $10 \%$ of the population of Northern Ireland has some ability in Irish (Census $\left.2011 \mathrm{KS} 209 \mathrm{NI}\right)$.

${ }^{44}$ This would be the case in general (where applicants must have satisfactory knowledge of a second official language) and in respect of language-related jobs such as lawyer-linguistic (where a higher level of knowledge is required).

${ }^{45}$ Enrolments at UK Higher Education Institutions: Northern Ireland Analysis - 2016/17, available at: https://www.economy-ni.gov.uk/sites/default/files/publications/economy/HE-Enrolments-bulletin-2016-17.pdf [last accessed 14 February 2019].

46 'Ministers McHugh and Mitchell O'Connor Announce Decision to Continue Supports for Prospective Higher Education Students Wishing to Study in the UK and UK Nationals Wishing to Take Up Studies in Ireland for the 2019/2020 Academic Year' https://www.education.ie/en/Press-Events/Press-Releases/2019-pressreleases/PR19-01-11a.html [last accessed 14 February 2019].
} 